\title{
THE EFFECT OF MATHEMATICAL SELF-EFFICACY ON THE STUDENTS' LEARNING OUTCOMES OF TEACHING PRACTICE PLACEMENT (PPL)
}

\author{
Sri Sulasteri' ${ }^{1}$, Fitriani Nur ${ }^{2}$, Suharti ${ }^{3}$ \\ 1,2,3 Teacher Training Faculty of UIN Alauddin Makassar \\ 1,2,3Jl. H.M. Yasin Limpo street Number 36 Samata-Gowa \\ Email: sri.sulasteri@uin-alauddin.ac.id¹, fitrianinur@uin-alauddin.ac.id², \\ suharti.harti@uin-alauddin.ac.id ${ }^{3}$
}

\begin{abstract}
:
This study aimed to investigates the effect of Mathematical self-efficacy on the students' learning outcomes of Teaching Practice Placement (PPL). This research used ex-post-facto with simple paradigm design. The population were 80 students' Department of Mathematics Education. Sampling technique used was saturated sample so that all the members of the population selected. The instruments used were questionnaire and documentation. The data were analyzed by using descriptive and inferential statistical analysis. The findings indicate that the average of the students' self-efficacy is 95.66 which is categorized as 'fair', the students' learning outcomes of teaching practice placement is 3.87 which is categorized as ' $\mathrm{A}$ ', and the regression gained through regression testwas $Y=2.359+0.016 \mathrm{X}$. Thus, there is significant effect of self-efficacy on the students' learning outcomes of Teaching Practice Placement.
\end{abstract}

\begin{abstract}
Abstrak:
Penelitian ini bertujuan untuk menyelidiki efek self-efficacy matematika pada hasil belajar mahasiswa dari Praktek Pengalaman Lapangan (PPL). Jenis penelitian ini menggunakan ex-post-facto dengan desain paradigma sederhana. Populasi terdiri dari 80 mahasiswa Jurusan Pendidikan Matematika. Teknik pengambilan sampel yang digunakan adalah sampel jenuh, sehingga semua anggota populasi dipilih. Instrumen yang digunakan terdiri dari kuesioner dan dokumentasi. Data dianalisis menggunakan analisis statistika deskriptif dan inferensial. Hasil penelitian ini menunjukkan bahwa rata-rata self-efficacy siswa adalah 95.66 dengan kategori 'sedang', hasil belajar siswa dari penempatan praktik mengajar adalah 3.87 dengan kategori 'A', dan persamaan regresi diperoleh melalui uji regresi, yaitu $Y=2.359+0.016 X$. Dengan demikian, ada pengaruh yang signifikan dari self-efficacy terhadap hasil belajar mahasiswa dari Praktek Pengalaman Lapangan.
\end{abstract}

\section{Keywords:}

Self-Efficacy of Mathematics, Learning Outcomes, Teaching Practice Placement

How to Cite: Sulasteri, S., Nur, F., \& Suharti. (2020). The Effect of Mathematical Self-Efficacy on the Students' Learning Outcomes of Teaching Practice Placement (PPL). Lentera Pendidikan : Jurnal Ilmu Tarbiyah dan Keguruan, 23(1), 98-107. https://doi.org/10.24252/lp.2020v23n1i9.

\section{INTRODUCTION}

Education is a process of change both individually and globally. Therefore, everyone is trying to get the best education with a goal to become better. Countries that want to develop are competing in improving their quality of public education (Suresh \& Kumaravelu, 2017). Indonesia, which is still a developing country, has made various efforts to improve the quality of education. One of the most important elements that should get attention is to produce qualified educators. Higher education which is oriented towards 
producing education personnel has a very big role to achieve goals in improving the quality of education. Therefore, universities must carry out various steps and strategies to produce qualified educators (Akareem \& Hossain, 2016).

Teaching Practice Placement, known as PPL in Indonesia. It is one of educational study programs which give the teacher students an opportunity to practice their teaching skills in schools that have collaborated with the universityto train prospective teachers to be able to master integrated teacher skills (Muhroji \& Setyanto, 2014). As a professional, a teacher is required not only to be able to carry out his/her duties as a teacher. It is guided and directed through PPL (Rhamayanti, 2018). Therefore, PPL is the basic of all teacher pre-service education programs. It is scheduled to take place after the teacher students have adequate knowledge in various studies.

The teaching skill must be accompanied by academic abilities related to teaching Mathematics in terms of Mathematical concepts, learning tools and teaching abilities in the class (Lubis et al., 2019). The implementation of PPL is one of the success benchmarks of higher education because all the elements needed in PPL process have been learnt by the students such as strengthening the knowledge of scientific disciplines specially Mathematics. This also becomes a place of self-actualization for the students to feel the real atmosphere of teaching before working in the community (Fidesrinur \& Fitria, 2016).

However, various problems found in the implementation of PPL include PPL students still expecting each other, students are not accustomed to teaching independently, and PPL students are not optimal in managing classes (Awaliyahputri, Syamsudduha, \& Shabir, 2019). So, evaluation of the students' performance in teaching practice is the part of assessing all courses that have been programmed before the Teaching Practice Placement.Therefore, the supervisor and tutor give scores to the students and it will be the benchmark success in the implementation of Teaching Practice Placement.

Learning theory developed by Edward L Thorndike revealed 3 laws of learning, namely the law of readiness, the law of practice, and the law of effect (Makki, 2019). If this theory is applied in the implementation of teaching practice, it is very necessary for the students' readiness to take teaching practice program both of their knowledge and physical readiness. By more teaching practice, the teacher students will love to teach, they are able to handle various conditions in the class, and they feel challenging to be a better teacher.

According to Winkel in Aidawati and Oktavia (2014: 64), learning outcomes are successful achievements in numerical form reached by the students in schools. Soedijarto in Rasdi (2015: 95) defines learning outcomes as high-level of comprehension reached by the students. Dimyati and Mudijono in Rosyidah (2016: 119) state learning outcomes are the result of teaching and learning interaction. In addition, Hamalik in Sulistyowati (2019: 2) says that learning outcomes are patterns of behavior, values, knowledge, attitudes, appreciation, abilities, and skills. Winarno Surakhmad in Stevani (2016: 310) also state that learning outcomes are test which aims to obtain an index in determining the students' success in studying. So we can concluded that learning outcomes are the results obtained 
by the students after following the teaching and learning process which proves the achievements that have been gained by them in the form of numbers.

Students' learning success is influenced by external and internal factors. One of the internal factors is self-efficacy which is introduced by Albert Bandura (Ernawati, 2013: 17). According to Bandura, self-efficacy is a person's belief in his/her ability to do specific duties or a part of a mission. According to Alwisol in Ilhamsyah (2012: 24), efficacy is selfassessment, whether an individual can do good or bad actions, right or wrong, and can or cannot do the duty as required. Self-efficacy describes the evaluation of self-abilities. A person who has high efficacy will have confidence that he/she is able to do a duty base on the situation, to work hard, and to persevere doing the responsibility until completion. Whereas Sullivan and Muhalik in Hayati (2010: 13) state that self-efficacy is a cognitive structure created by cumulative learning experiences that will form a sense of belief or confidence that he/she can complete the duty very well.

According to Bandura, someone who believes in his/her abilities has the ability to change things in their environment by acting actively than those who has lower selfefficacy (Widiyanti \& Marhaeni, 2013). Therefore, it can be concluded that self-efficacy is the students' belief about the extent of their ability to take appropriate action in overcoming obstacles related to the tasks given by the advisors.

Bandura in Ilhamsyah (2012: 27) states that self-efficacy has three dimensions. The first is level dimension. Level dimension is the difficult level of the required task, how hard it can be completed. If the difficulty level is too high, it will be difficult to do so. Likewise, if the level of difficulty is too low, it will be too easy to do it. The second is generality. It can be interpreted as the extent of the confidence level in his/her abilities relates to the scope of the task. The third dimension is strength. It means the confidence level of abilities relates to the readiness. The more ready an individual is in carrying out the task, it will be easier to do even though the task is actually quite difficult (Ilhamsyah 2012: 27).

Self-efficacy develops in line with the human development. The higher the duty, the more difficult it will be. Therefore, self-efficacy will not be static. Efficacy can be reduced and increased depending on how a person evaluates each phase of his/her life (Widyaninggar, 2014: 93). One can improve his/her self-efficacy through experience, both his/her own experiences or others' (Dewanto, 2018: 3).

Based on the interview with one of the advisors in school, several students were still unable to teach in the class. It does not mean they have low academic skill, but their lack of confidence to teach in the class as required for them to do Teaching Practice Placement to pass the course at the end of the semester. If the teacher students believe their abilities, they will have strength to do their best to implement their knowledge that they have learned. In addition, the teacher students during teaching placement were sometimes lazy to come to school, lack of class control, and also doing Teaching Practice Placement only to fulfill the required course without responsible as an educator.

A research conducted by Suharti, Darwis, \& Anas (2015) about the effect of selfefficacy on learning outcomes explained that self-efficacy had positive effect on learning outcomes in Mathematics. In other research conducted by Apsari, Adi, \& Octoria (2014) concluded that there was significant effect of self-efficacy on students' accounting learning 
achievement. PPL is a direct teaching practice in schools so that researchers are interested in the relationship of students' self-efficacy in joining the mathematics program. And what distinguishes from previous relevant research is the value of PPL is the value of the results of field practice not the value of cognitive tests. These findings interest the researcher to conduct a research related to the effect of Mathematical self-efficacy on the students' scores in Teaching Practice Placement (PPL) of Mathematics Education Department batch 2015.

\section{RESEARCH METHOD}

This research used ex-post-facto with simple paradigm design. It has one independent variable and one dependent variable. The independent variable is Mathematical self-efficacy $(\mathrm{X})$ and the dependent variable is the learning outcomes of Teaching Practice Placement (Y). Mathematical self-efficacy variables are developed based on indicators consisting of level, generality, and strength. PPL learning value intended in this study is the final value of the implementation of PPL in schools. The population were 80 students majoring Mathematics Education batch 2015. Sampling technique used was saturated sample so that all the members of the population selected. The instruments used were questionnaire and documentation. The data were analyzed by using descriptive and inferential statistical analysis. Descriptive analysis consists of the average score of the students' self-efficacy and the average value of the students' learning outcomes of Teaching Practice Placement (PPL), while inferential statistical analysis used regression test.

\section{RESULT AND DICUSSION}

The questionnaire scores of self-efficacy given to PPL students consisting of five categories which are developed in likert-scale form can be seen on the following frequency distribution table:

Table 1. Distribution of Mathematical Self-Efficacy Scores

\begin{tabular}{ccccc}
\hline No. & Score & Frequency & Percentage (\%) & Category \\
\hline 1 & $30 \leq \mathrm{SE}<67.5$ & 0 & 0 & Very Low \\
2 & $67.5 \leq \mathrm{SE}<82.5$ & 11 & 13.75 & Low \\
3 & $82.5 \leq \mathrm{SE}<97.5$ & 33 & 41.25 & Fair \\
4 & $97.5 \leq \mathrm{SE}<112.5$ & 29 & 36.25 & High \\
5 & $112.5 \leq \mathrm{SE} \leq 120$ & 7 & 8.75 & Very High \\
\hline & Total & 80 & 100 & \\
\hline Mean & Std. Deviation & Variance & Minimum & Maximum \\
\hline 95.66 & 11.708 & 137.087 & 70 & 120 \\
\hline
\end{tabular}

Based on table 1, the maximum and minimum scores are 120 and 70 respectively with 11.708 of the standard deviation and 137.087 of the variance. The average score of Mathematical self-efficacy is 95.66 which means the Mathematical self-efficacy scores are in fair category. None of the students includes in low category. Standard deviations 
indicate heterogeneity or it can be said the average of variability in a set of observational data. The greater is the score of the standard deviation, the greater is the average gap of each unit of mean scores. It happens because the standard deviation is calculated as the average gap of all observational data to the mean point so that the standard deviation is very low which shows the smaller average gap with the mean point.

Based on the scores achieved by the students in implementing PPL which are divided into five categories namely $(A, B, C, D$, and E) can be seen on the following frequency distribution table:

Table 2. Distribution of Students' Scores in Teaching Practice Placement (PPL)

\begin{tabular}{ccccc}
\hline No. & Score & Frequency & Percentage (\%) & $\begin{array}{c}\text { Category of } \\
\text { Learning } \\
\text { Outcome }\end{array}$ \\
\hline 1 & 0 & 0 & 0 & $\mathrm{E}$ \\
2 & 1 & 0 & 0 & $\mathrm{D}$ \\
3 & 2 & 1 & 1.43 & $\mathrm{C}$ \\
4 & 3 & 8 & 10 & $\mathrm{~B}$ \\
5 & 4 & 71 & 88.75 & $\mathrm{~A}$ \\
\hline \multicolumn{7}{c}{ Total } & 80 & 100 & Maximum \\
\hline 3.87 & Std. Deviation & Variance & Minimum & 4 \\
\hline
\end{tabular}

Table 2 shows that the maximum and the minimum scores are 4 and 2 respectively with 0.369 of standard deviation and 0.136 of the variance. The average score of the students' learning achievement in Teaching Practice Placement is 3.87, which is categorized as A.

Kolmogorov-Smirnov test and linearity test are used to find out whether the research data are normal or not which aims to find out whether two variables have linear correlation or not significantly. The following is the normality and linearity tests of PPL students' self efficacy research data in implementing mathematics learning that can be seen on the following table:

Table 3. Normality Test

\begin{tabular}{lcccccc}
\hline & \multicolumn{2}{c}{ Kolmogorov-Smirnov(a) } & \multicolumn{3}{c}{ Shapiro-Wilk } \\
& Statistic & Df & Sig. & Statistic & Df & Sig. \\
\hline Teaching Placement & .520 & 80 & .01 & .374 & 80 & .11 \\
Self-Efficacy & .127 & 80 & .003 & .972 & 80 & .078 \\
\hline
\end{tabular}

Based on table 3, it is found that variables of Mathematical self-efficacy and the students' learning outcomes in Teaching Practice Placement (PPL) are normally distribution because the sig value is higher than 0.05 . 
Table 4. Linearity Test

\begin{tabular}{llcccccc}
\hline & & $\begin{array}{c}\text { Sum of } \\
\text { Squares }\end{array}$ & df & $\begin{array}{c}\text { Mean } \\
\text { Square }\end{array}$ & F & Sig. \\
\hline $\begin{array}{l}\text { Teaching } \\
\text { Placement } * \\
\text { Self-Efficacy }\end{array}$ & $\begin{array}{l}\text { Between } \\
\text { Groups }\end{array}$ & (Combined) & & & & & \\
& & 7.450 & 39 & .191 & 2.315 & .005 \\
& $\quad \begin{array}{l}\text { Linearity } \\
\text { Deviation } \\
\text { from }\end{array}$ & 2.720 & 1 & 2.720 & 32.967 & .0001 \\
& $\quad 4.730$ & 38 & .124 & 1.509 & .101 \\
& $\begin{array}{l}\text { Linearity } \\
\text { Within Groups }\end{array}$ & 3.300 & 40 & .083 & & \\
\hline
\end{tabular}

Based on table 4, it shows the Mathematical self-efficacy $(\mathrm{X})$ and the students' learning outcomes of Teaching Practice Placement $(\mathrm{Y})$ have linear relationship because the sig value is $>0.05$.

To determine the effect of Mathematical self-efficacy on students' learning outcomes in Teaching Practice Placement (PPL), simple linear regression analysis is used. The output is as follows.

Table 5. Significance Test of Simple Linear Regression Coefficient

\begin{tabular}{ccc}
\hline Model & $\mathbf{R}^{2}$ & p-value (sig) \\
\hline $\mathrm{X}_{1} \mathrm{Y}$ & 0.253 & 0.0001 \\
\hline
\end{tabular}

Based on table 5, the score $\mathrm{R}^{2}$ (R Square) or determination is 0.253 or $(25.3 \%)$. It indicates that the percentage of Mathematical self-efficacy contribution to the learning outcomes of thestudents' teaching Practice (PPL) is $25.3 \%$ while the value of sig. $<0.05$ $(0.0001<0.05)$, then $\mathrm{H} 0$ is rejected. There is $74.7 \%$ influenced by other factors which are not discussed in this study. Thus, it can be concluded that there is a significant effect of Mathematical self-efficacy on the students' learning outcomes of Teaching Practice Placement (PPL).

Table 6. Simple Linear Regression Coefficient

\begin{tabular}{llcccccc}
\hline Model & & \multicolumn{2}{c}{$\begin{array}{c}\text { Unstandardized } \\
\text { Coefficients }\end{array}$} & $\begin{array}{c}\text { Standardized } \\
\text { Coefficients }\end{array}$ & T & Sig. \\
& & B & Std. Error & Beta & B & Std. Error \\
\hline 1 & & (Constant) & 2.359 & .297 & & 7.940 & .0001 \\
& Self-Efficacy & .016 & .003 & .503 & 5.140 & .0001 \\
\hline
\end{tabular}

Based on table 6, the simple linear regression coefficient shows 2.359 of constant coefficient and 0.016 of independent variablecoefficient (X). It means that the simple linear regression equation is as follows.

$$
\mathrm{Y}=2.359+0.016 \mathrm{X}
$$


The results of inferential statistical analysis were used to answer the hypotheses of the problems in this study. However, the data were tested previously for normality and linearity test. The finding indicated that the questionnaire data of Mathematical selfefficacy and students' learning outcomes were normal and had a linear relationship. Because the data were normally distributed and there was a linear relationship, the results of the subsequent research data were analyzed with simple linear regression to answer the hypotheses in this study.

Based on the analysis result, the contribution of Mathematical self-efficacy toward learning outcomes was $25.3 \%$. There was about $74.7 \%$ influenced by other variables which were not discussed in this study. The result of the simple linear regression equation indicated that the average of the students learning outcomes was 2.359 if it was not influenced by Mathematical self-efficacy. However, if the improvement of each Mathematical self-efficacy was 1 , the average of learning outcome would increase 0.016 . It meant that Mathematical self-efficacy had positive effect on the students' learning outcomes in Teaching Practice Placement (PPL). The students who had high self-efficacy prepared themselves to learn well to receive good learning outcomes. This result is supported by others, like by Wahdania, Rahman, \& Sulasteri (2017: 78); Fitriana, Ihsan, \& Annas (2015: 100); Sihaloho, Rahayu, \& Wibowo (2018: 62); Widyaninggar (2014: 98); Tuhardjo, Juliardi, \& Arief Rafsanjani (2016: 9); Monika \& Adman (2017: 113).

According to Huang (2016: 126), self-efficacy is a person's confidence that he/she is able to complete or carry out academic tasks. The approach used to overcome the problem of the self-efficacy influence on learning outcomes is using Bandura theory which states that self-efficacy is a belief in the ability of individual to be able to handle and carry out a series of actions if necessary in achieving the result. Someone who has strong self-efficacy will increase their personal achievement and well-being in a variety of strategies, so the students who have high self-efficacy tend to have high achievements (Sihaloho, Rahayu, \& Wibowo, 2018: 65).

Based on data analysis in this research, it was found that the higher was the level of Mathematical self-efficacy, the higher was the students' learning outcomes. This result was in line with the research conducted by Sihaloho, Rahayu, \& Wibowo (2018: 68)which concluded that the students' success in getting good learning outcomes could be seen from their self-efficacy level. The higher was the students' self-efficacy level in learning, the more encourage the students to get optimal learning outcomes. Panjares in Niehaus, Rudasill, \& Adelson (2012) explained that the students with higher academic self-efficacy got higher grades, had higher goals for themselves, and showed greater effort and perseverance in their work.

The latest information in this study is the need to strengthen student self-efficacy in order to teach well, even though students are academically intelligent but have no confidence in teaching; the knowledge possessed cannot be shared to the students. This is what distinguishes this research from Awaliyahputri, Syamsudduha, \& Shabir (2019) who examines the implementation of PPL in the UIN Alauddin partner school. 


\section{CONCLUSION}

Based on the research findings and discussion, it could be concluded that the average score of the students' self-efficacy is $\mathbf{9 5 . 6 6}$ which is categorized as 'fair' and the average value of the students' learning outcomes of Teaching Practice Placement (PPL) is 3.87 which is categorized as ' $A$ '. The findings indicate that there is significant effect of selfefficacy on the students' learning outcomes of Teaching Practice Placement (PPL). It is proved by the data analysis using regression test that the regression equation obtained is $\mathrm{Y}=2.359+0.016 \mathrm{X}$. Based on hypothesis test, it is concluded that there is significant effect of self-efficacy on the students' learning outcomes of Teaching Practice Placement. The researchers suggest some points as follows: (1) in improving the students' Mathematical learning outcomes at all levels of Mathematics Education Department of UIN Alauddin Makassar, one of the efforts that can be done is to grow and to improve the students' selfefficacy; and (2) to further researchers, it is expected to develop this research so that it is able to complete the weakness of this study by examining other factors that affect learning outcomes, such as family, environment, and so forth.

\section{REFERENCES}

Aidawati, \& Oktavia, R. (2014). Meningkatkan Hasil Belajar Siswa dengan Implementasi Pendekatan Pembelajaran Konstruktivisme Materi Perubahan Lingkungan di SD Negeri Geulumbang Aceh Barat. Jurnal Binagogik, 1(1), 47-64. https://ejournal.stkipbbm.ac.id/index.php/pgsd/article/view/92.

Akareem, H. S., \& Hossain, S. S. (2016). Determinants of Education Quality: What Makes Students'. Determinants of Education Quality: What Makes Students' Perception Different?. Open Review of Educational Research, 3(1), 52-67. https://doi.org/10.1080/23265507.2016.1155167.

Apsari, B. S., Adi, W., \& Octoria, D. (2014). Pengaruh Efikasi Diri, Pemanfaatan Gaya Belajar, dan Lingkungan Teman Sebaya terhadap Prestasi Belajar Akuntasi. Jupe UNS, 3(1), 91-102.

Awaliyahputri B., N., Syamsudduha, S., \& Shabir U., M. (2019). Alasan Mahasiswa Praktik Pengalaman Lapangan (PPL) Belum Menguasai Keterampilan Dasar Mengajar. Jurnal Idaarah, 3(1), 68-80. https://doi.org/https://doi.org/10.24252/idaarah.v3i1.7937.

Dewanto, A. C. (2018). Efektivitas PPL untuk Meningkatkan Efikasi Diri Mengajar pada Mahasiswa Pendidikan Matematika. Delta: Jurnal Ilmiah Pendidikan Matematika, 6(1), 1-9. https://doi.org/10.31941/delta.v6i1.662.

Ernawati. (2013). Pengaruh Efikasi Diri, Konsep Diri, Aktivitas Belajar, dan Kemandirian Belajar terhadap Hasil Belajar Matematika pada Siswa Kelas VII SMP Negeri SeKecamatan Somba Opu. Thesis. Universitas Negeri Makassar.

Fidesrinur, \& Fitria, N. (2016). Praktik Pengalaman Lapangan Studi Evaluatif terhadap Pelaksanaan PPL Mahasiswa PAUD Universitas Al Azhar Indonesia Tahun 2015/2016. Jurnal Al-Azhar Indonesia Seri Humaniora, 3(4), 346-358. https://doi.org/http://dx.doi.org/10.36722/sh.v3i4.228. 
Fitriana, S., Ihsan, H., \& Annas, S. (2015). Pengaruh Efikasi Diri, Aktivitas, Kemandirian Belajar, dan Kemampuan Berpikir Logis terhadap Hasil Belajar Matematika pada Siswa Kelas VIII SMP. Journal of Educational Science and Technology (EST), 1(2), 86-101. https://doi.org/10.26858/est.v1i2.1517.

Hayati, M. (2010). Hubungan Kemampuan Metakognitif dan Efikasi Diri dengan Prestasi Keterampilan Laboratorium Kimia Analitik Mahasiswa Analis Kesehatan. UNS.

Huang, C. (2016). Achievement Goals and Self-Efficacy: A Meta-Analysis. Educational Research Review, 19, 119-137. https://doi.org/10.1016/j.edurev.2016.07.002.

Ilhamsyah. (2012). Pengaruh Efikasi Diri, Metakognisi dan Regulasi Diri terhadap Prestasi Belajar Matematika Siswa Kelas X SMA Negeri di Kabupaten Wajo. Thesis. Universitas Negeri Makassar.

Lubis, A., Hanafi, \& Siregar, R. A. (2019). Analisis Kebutuhan Sistem Pengelolaan Microteaching dengan Siklus Penetapan, Pelaksanaan, Evaluasi, Pengendalian dan Peningkatan (PPEPP) dalam Meningkatkan Keterampilan Mengajar Calon Guru Institut Pendidikan Tapanuli Selatan. Jurnal Education dan Development, 7(3), 5763. https://doi.org/10.37081/ed.v7i3.1162.

Makki, A. (2019). Mengenal Sosok Edward Lee Thorndike Aliran Fungsionalisme dalam Teori Belajar. PANCAWAHANA: Jurnal Studi Islam, 14(1), 78-91. http://ejournal.kopertais4.or.id/tapalkuda/index.php/pwahana/article/view/33 53.

Monika, \& Adman. (2017). Peran Efikasi Diri dan Motivasi Belajar dalam Meningkatkan Hasil Belajar Siswa Sekolah Menengah Kejuruan. Jurnal Pendidikan Manajemen Perkantoran, 2(2), 109-116. https://doi.org/10.17509/jpm.v2i2.8111.

Muhroji, \& Setyanto, C. B. (2014). Model Pengelolaan Program Pengalaman Lapangan Program Studi Guru Sekolah Dasar FKIP UMS. Profesi Pendidikan Dasar, 1(2), 149161. https://doi.org/https://doi.org/10.23917/ppd.v1i2.1007.

Niehaus, K., Rudasill, K. M., \& Adelson, J. L. (2012). Self-Efficacy, Intrinsic Motivation, and Academic Outcomes Among Latino Middle School Students Participating in an After-School Program. Hispanic Journal of Behavioral Sciences, 34(1), 118-136. https://doi.org/10.1177/0739986311424275.

Rasdi. (2015). Pengaruh Model Pembelajaran Kooperatif Tipe Snowball Drilling terhadap Hasil Belajar Matematika Siswa Kelas X SMA Nusantara Kota Jambi. Dikdaya, 5(1), 94-100. https://doi.org/http://dx.doi.org/10.33087/dikdaya.v5i1.69.

Rhamayanti, Y. (2018). Pentingnya Keterampilan Dasar Mengajar bagi Mahasiswa Praktik Pengalaman Lapangan (PPL) Prodi Pendidikan Matematika. Eksakta Jurnal Penelitian Dan Pembelajaran MIPA, 3(1), 65-72. https://doi.org/http://dx.doi.org/10.31604/eksakta.v3i1.65-72.

Rosyidah, U. (2016). Pengaruh Model Pembelajaran Kooperatif Tipe Jigsaw terhadap Hasil Belajar Matematika Siswa Kelas VIII SMP Negeri 6 Metro. Jurnal SAP (Susunan Artikel Pendidikan), 1(2), 115-124. https://doi.org/10.30998/sap.v1i2.1018.

Sihaloho, L., Rahayu, A., \& Wibowo, L. A. (2018). Pengaruh Efikasi Diri (Self Efficacy) terhadap Hasil Belajar Ekonomi Siswa Kelas XI IPS SMA Negeri Se-Kota Bandung. JINoP Jurnal Inovasi Pembelajaran), 4(1), 62-70. https://doi.org/https://doi.org/10.22219/jinop.v4i1.5671.

Stevani. (2016). Analisis Pengaruh Motivasi Belajar terhadap Hasil Belajar Ekonomi Siswa Kelas X SMA Negeri 5 Padang. ECONOMICA Journal of Economic and Economic Education, 4(2), 308-314. https://doi.org/10.22202/economica.v4i2.669. 
Suharti, Darwis, M., \& Anas, S. (2015). Pengaruh Pola Asuh Demokratis, Interaksi Sosial Teman Sebaya, Kecerdasan Emosional, dan Efikasi Diri terhadap Hasil Belajar Matematika Siswa Kelas VIII SMPN Se Kecamatan Manggala di Kota Makassar. Jurnal Daya Matematis, 3(1), 10-19. https://doi.org/10.26858/jds.v3i1.1292.

Sulistyowati, E. (2019). Meningkatkan Keterampilan dan Hasil Belajar Bahasa Indonesia tentang Menulis Surat Resmi melalui Contextual Teaching and Learning (CTL) pada Siswa Kelas VI SD 6 Getassrabi. Inopendas Jurnal Ilmiah Kependidikan, 2(1), 1-8. https://doi.org/10.24176/jino.v2i1.3436.

Suresh, E. S. M., \& Kumaravelu, A. (2017). The Quality of Education and Its Challenges in Developing Countries. 2017 ASEE International Forum, 1-9.

Tuhardjo, T., Juliardi, D., \& Arief Rafsanjani, M. (2016). The Effect of Learning Effectiveness and Self-Efficacy on Intermediate Financial Accounting I Learning outcome. IOSR Journal of Humanities and Social Science, 21(9), 1-9. https://doi.org/10.9790/0837-2109080109.

Wahdania, Rahman, U., \& Sulasteri, S. (2017). Pengaruh Efikasi Diri, Harga Diri, dan Motivasi terhadap Hasil Belajar Matematika Peserta Didik Kelas X SMA Negeri 1 Bulupoddo Kab. Sinjai. MaPan : Jurnal Matematika Dan Pembelajaran, 5(1), 68-81. https://doi.org/10.24252/mapan.2017v5n1a5.

Widiyanti, M. D., \& Marhaeni, A. (2013). Perbedaan Efikasi Diri Berdasarkan Tipe Pola Asuh Orangtua pada Remaja Tengah di Denpasar. Jurnal Psikologi Udayana, 1(1), 171180. https://doi.org/https://doi.org/10.24843/JPU.2013.v01.i01.p17.

Widyaninggar, A. A. (2014). Pengaruh Efikasi Diri dan Lokus Kendali (Locus of Control) terhadap Prestasi Belajar Matematika. Jurnal Formatif, 4(2), 89-99. http://dx.doi.org/10.30998/formatif.v4i2.143. 